rates of younger and older workers can also be deceiving. The fact is that the bachelor's degree attainment rate in the United States has climbed steadily throughout the past several decades. How can this be so if the younger and older workers have the same rate of attainment? The answer is that if the attainment rate is the same for younger and older workers, attainment most likely is rising. The explanation is that the younger workers will have higher rates than today's older workers since as they age additional members of the cohort will attain a degree, thus leading to higher rates.

In sum, the United States continues to have among the highest participation rates among OECD countries, below average rates of completion, among the highest attainment rates for bachelor's degrees, and average to below average attainment rates for subbachelor's degrees. These rankings are not necessarily inconsistent. A high proportion of American high school graduates enroll in tertiary education, many do not complete their degrees; but since so many enroll, attainment is high at least for bachelor's degrees. One key conclusion from this analysis is that a key challenge for the United States is to figure out how to improve the degree completion rate of its community college students.

\section{For-Profit Universities in the Political Economy of Higher Education}

\section{Brian Pusser}

Brian Pusser is associate professor in the Center for the Study of Higher Education at the University of Virginia, Charlottesville, Virginia, USA. Email:bp6n@virginia.edu.

$\mathrm{O}$ ver the past two decades, higher education research has turned much of its attention to the purpose and effectiveness of various institutional forms of postsecondary education. In the United States, a national system long dominated by nonprofit public and private degree-granting institutions has recently had to give some attention to the more prominent forprofit colleges and universities. While they account for only a small percentage of postsecondary enrollments, for-profit institutions - particularly publicly traded higher education corporations such as the University of Phoenix-loom much larger in the political economy of US higher education than their size would lead one to expect. In negotiations over the reauthorization of the Higher Education Act, the for-profit universities and their lobbying organizations have played a unique role in shaping policies affecting all higher education institutions.
The emergence of this sector offers important lessons for the future of higher education in the United States and many other countries in which for-profit education is offered or contemplated.

\section{For-Profits, Markets, and the State}

The neoliberal restructuring programs, in ascendance globally since the I970s, rely on a simple belief: the role of the state in the production of public and private goods should be reduced in favor of market competition wherever possible. To evaluate the possible impact of neoliberal policies on colleges and universities, scholars have addressed the complex nature of higher education as both a public and private good as well as the traditional state role regarding problematic aspects of the market production of education such as information asymmetry, moral hazard, and underinvestment. The United States has long been a mixed system with a great deal of direct government provision through public nonprofit institutions as well as direct and indirect government subsidies for public nonprofit institutions and indirect subsidies (primarily through student aid and tax policies) to private nonprofit and for-profit institutions. That system has also been highly regulated at the state and federal level.

The political argument for shifting direct subsidies from government provision to a more competitive resource allocation system asserts that essential public interests can be protected through regulations designed to shape market behaviors. It is a powerful claim, one that questions what it is that the country will need to regulate and how effective the regulation will be. While there is some consensus that states need to regulate to ensure the appropriate balance of public and private goods for the continued success of the national postsecondary project, little general agreement exists on the forms of regulation or the nature of that balance. How effectively a marketized higher education system can be regulated is a rarely addressed question in research on higher education. The rise of for-profit degree-granting universities offers insight into the question and points usefully to the need for further inquiry.

\section{Universities in the Political Arena}

Although they are not often described as such, colleges and universities in the United States and many other national contexts are political institutions. They entail significant public costs and allocate essential public benefits in a process determined by political action. The key issues of resource allocation and regulation for higher education in the United States are served by the adjudication of various demands through state and national political structures. This factor creates powerful incentives for postsecondary institutions to make their interests clear in the political process.

Lobbying represents one of the most effective forms of political action-devoting human and financial resources to raising issues, information, and arguments before legislators and individuals in a position to influence legislation. In the 
United States postsecondary lobbying has increased significantly over the past two decades as public and private nonprofit institutions have sought "earmarked" funding from the US Congress. Working individually, with hired lobbyists and through associations, nonprofit and for-profit institutions have also endeavored to influence legislation on a variety of higher education issues, as have private student-loan providers and others pursuing education-related commerce.

\section{FOR-PROFIT LOBBYING}

Lobbying is an arena in which for-profits have a number of structural advantages over nonprofit institutions. For-profits can provide direct political contributions to legislators and political parties. Indeed, the leaders of the House and Senate committees that guide legislation relevant to higher education have received significant support from for-profit colleges and affiliated interest groups. Given their relatively narrow focus, many for-profit universities are well positioned to target resources on a few essential issues. While nonprofits seek to use political support to maximize a variety of public and private goods, lobbying by proprietary institutions has one ultimate goal-shaping legislation to maximize profit.

As mentioned earlier, for-profit colleges and universities in the United States have been extremely active in the reauthorization of the Higher Education Act, seeking to shape federal regulations governing institutional eligibility for aid, distance

The United States has long been a mixed system with a great deal of direct government provision through public nonprofit institutions as well as direct and indirect government subsidies for public nonprofit institutions.

learning, and the standardization of credit transfer. For-profits have also been prominent in lobbying at the state level. For example, the Chronicle of Higher Education reports that for-profit colleges spent nearly $\$ 500,000$ during a recent session of the California legislature. These efforts have led to a number of challenges to existing policies that will likely be manifest in emerging legislation. For-profit universities have had a disproportionate impact in the higher education lobbying arena, given that only about 6 percent of postsecondary students in the United States are enrolled in for-profit institutions.

\section{CONCLUSION}

Can states preserve regulations that protect the public and private benefits of higher education while satisfying the profit demands of an evolving postsecondary market? As with most political contests, much will depend on the ability of a variety of postsecondary stakeholders to become involved in the political arena shaping higher education. Future research on the tension between states and markets will benefit from turning attention to the evolving balance of political legitimacy, lobbying, and policy challenges evidenced in the rise of for-profit degree-granting colleges and universities.

\section{Knowledge Economies: The Singapore Example}

\section{Ravinder Sidhu}

Ravinder Sidhu is on the staff of the School of Education, University of Queensland, Australia. Address: Social Science Building, University of Queensland, St. Lucia, Brisbane 4072, Australia. E-mail: r.sidhu@uq.edu.au.

S ingapore has been noted for its foresight in matters relating to its economic development, and since it has drawn up plans to rebuild itself into an innovation-led, value-added knowledge economy. These policy efforts were strengthened following the 1997 Asian financial crisis. Henceforth Singapore would direct significant resources toward transforming itself into an education and medical services hub. Although its knowledge-economy aspirations are not especially exceptional-Romania, Ireland, and Malaysia number among countries those with similar goals-Singapore's singleminded pursuit of these goals is unique.

\section{The Global Schoolhouse}

Singapore's government formulated the Global Schoolhouse, a policy platform based on three pillars: investing financial support with an identified group of "world-class universities" to establish operations in Singapore; attracting I50,000 international students by 2015 to study in both private and state-run education institutions; and remodel all levels of Singaporean education. The Global Schoolhouse articulates with policy reforms in education, research, urban redevelopment, taxation, immigration, and intellectual property.

The policy strategy of inviting foreign world-class universities to Singapore rests on exploiting their "brand equity." Research-intensive American institutions initially dominated among those invited: Massachusetts Institute of Technology, Georgia Tech, and Duke University were funded to run graduate-level programs, while Johns Hopkins University was to conduct biomedical research and provide doctoral training. The University of Chicago Graduate School of Business was assisted to establish a campus in a refurbished heritage building, and Wharton Business School was contracted to provide expertise in setting up Singapore's third university, Singapore Management University. The field has since widened to include non-American universities and institutions that focus 